\title{
S-18-2 Zinc Status in Proliferative Response of T Lymphocytes
}

\author{
M.Ohsawa, F.Otsuka, and S.SugizaKi
}

Department of Environmental Toxicology, Faculty of Pharmaceutical Sciences, Teikyo University, Suarashi, Sagamiko, Kanagawa 199-01 (Japan)

\section{INTRODUCTION}

In man and animals in zinc ( $\mathrm{Zn}$ ) deficiency or with hereditary malabsorption of $\mathrm{Zn}$, immunological disturbance as well as growth retardation has been described, including involution of thymus and lymphoid organs and increased susceptibility to infection $[1,2]$. Such immunological disturbance are restored by oral or parenteral administration of $\mathrm{Zn}$ compounds. Since the first observation on dysfunction of cell-mediated immunity in Zn-deprived mice [3], experimental studies with dietary $Z n$ deficiency as a single nutritional variable have shown a significant depression of $T$ cell proliferation and function as shown in Table 1 [4]. $\mathrm{Zn}$ is thus considered as a critical biofactor to regulate $T$ cell-dependent immune response through $\mathrm{Zn}$-dependent immune processes. An in vitro experiment moreover shows that proliferative response of $T$ cells are more susceptible to $\mathrm{Zn}$ depriviation with chelating agent compared with that of $B$ cells [5]. It is much of interest why T cells are highly susceptible to depriviation of $\mathrm{Zn}$.

Although lymphocyte proliferation requires $\mathrm{Zn}$ as an essential nutrient [6]. the precise mechanism for $\mathrm{Zn}$-dependent immune processes, in particular the selective requirement of $Z$ n by $T$ cells, is not clear. Recent findings indicate that $Z n$ plays a critical role in activation of a thymic hormone, thymulin, which promotes proliferation and differentiation of immatured thymocytes [7]. On the other hand, $\mathrm{Zn}$ is well known as a cofactor of many enzymes and transcription factors necessary for DNA replication and RNA transcription, e.g. DNA and RNA polymerases, thymidine kinase and transcription factor A [8]. Moreover, $Z n$ has been suggested to regulate signal transduction in $T$ cells through activation and translocation of protein kinase $C[9,10]$. However, these are not enough to explain the selective dependency of matured $T$ cells to $\mathrm{Zn}$.

We find that proliferative response of cultured mouse spleen cells to $T$ cell mitogens, concanavalin $A$ (Con $A$ ) and phytohemagglutinin (PHA), are more

TABLE 1.

Immunological alterations caused by nutritional zinc restriction as a single nutritional variable.

1. Defficiency of $T$ cell number

2. Reduced proliferative responses of $T$ cells to phytomitogens, allogeneic cells and common antigens

3. Decreased T cell-dependent antibody production, e.g. in primary antibody response to sheep red blood cells

4. Decreased tempo of skin allograft rejection

5. Decreased natural killer cell activities

6. Decreased functional activity levels of thymulin

7. Decreased accessary function of macrophages for proliferative response of $T$ cells to a phytomitogen (PHA) 
susceptible to cadmium (Cd) than that to $B$ cell mitogen, lipopolysaccharide (LPS) [11]. The differential susceptibility to $\mathrm{Cd}$ of mitogen responsiveness between $T$ and $B$ cells is similar to that to the in vitro $Z n$ deficiency [5]. In fact the inhibition of $T$ cell proliferation by $C d$ are protected by simultaneous addition of $\mathrm{Zn}$ [12]. This suggests that $\mathrm{Zn}$-dependent processes in proliferative response of $T$ cells can be the sensitive target(s) of Cd toxicity. Then, in order to define $Z n$ status in $T$ cell proliferation, we further studied toxicological situation of $\mathrm{Zn}$ in proliferative responses of $\mathrm{T}$ cells to Con A [13], and also have done a biochemical approach to detect $\mathrm{Zn}$-dependent molecules induced during $T$ cell proliferation.

\section{ZINC STATUS IN THE SUSCEPTIBILITY OF PROLIFERATIVE RESPONSE OF T LYMPHO- CYTES TO CADMIUM}

1. Specific Implication of Zinc in the Susceptibility of T Cell Proliferation First, we tried to characterize the differential susceptibility to Cd of mitogen responsiveness between $T$ and $B$ cells in cultured spleen cells of $\mathrm{BALB} / \mathrm{c}$ mice. Results are obtained as follows: (1) the differential susceptibility to $\mathrm{Cd}$ is observed on both DNA and RNA synthes is induced by mitogens, Con A $(2 \mu \mathrm{g} / \mathrm{ml})$ and LPS $(20 \mu \mathrm{g} / \mathrm{ml})$. (2) High susceptibility of T cell proliferation is characteristic of $\mathrm{Cd}$, because in the comparative study with various heavy metal compounds there were no similarities in their effects on the mitogen-induced DNA synthesis between $\mathrm{Cd}$ and other heavy metals such as $\mathrm{Pb}_{\text {, }}$ $\mathrm{Hg}(\mathrm{II}), \mathrm{Ni}, \mathrm{Mo}, \mathrm{Ag}, \mathrm{Cr}(\mathrm{VI})$ and $\mathrm{As}(\mathrm{V})$. (3) The early events during the response

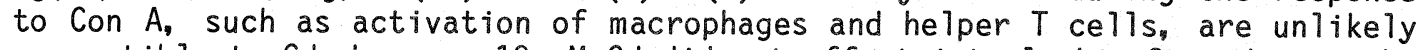
susceptible to $\mathrm{Cd}$, because $10 \mu \mathrm{M} \mathrm{Cd}$ did not affect interleukin-2 production by activated helper $T$ cells precedent to $T$ cell proliferation. (4)The inhibition by $\mathrm{Cd}$ at around $10 \mu \mathrm{M}$ of Con A-induced proliferative response of $\mathrm{T}$ cells was mostly protected by simultaneous addition of $30 \mu \mathrm{M} Z \mathrm{n}_{\text {. }}$ The protection from the inhibitory effect of $\mathrm{Cd}$ was obtained only with $\mathrm{Zn}$ among 4 essential divalent metals: $\mathrm{Zn}, \mathrm{Cu}_{v} \mathrm{Fe}$ and $\mathrm{Ni}$. These findings indicate that $\mathrm{Zn}$-dependent processes are specifically implicated in the susceptiblility of $T$ cell proliferation to $\mathrm{Cd}$.

\section{The Zinc-dependent Processes Required for T Cell Proliferation Should be}

Targets Susceptible to Cadmium

There are two possibile explanations for the protective effect of $\mathrm{Zn}$ on the inhibitory action of Cd to T cells: first, $\mathrm{Zn}$ may decrease effective concentration of $\mathrm{Cd}$ in $\mathrm{T}$ cells, through reduction of $\mathrm{Cd}$ uptake or induction of metallothionein which binds $\mathrm{Cd}$. Second, $\mathrm{Zn}$ may compete with $\mathrm{Cd}$ on $\mathrm{Zn}$-dependent processes required for $T$ cell proliferation. To estimate these possibilities, we examined effect of $\mathrm{Zn}$ added at the protecting dose on cellular uptake and distribution of ${ }^{109} \mathrm{Cd}$ ( $\mathrm{Cd}$ in whole cell, cytoplasm and crude nuclei, and metallothionein-bound $\mathrm{Cd}$ ) in spleen cell cultures. In spleen cells at $24 \mathrm{~h}$ after Con A-stimulation the addition of $\mathrm{Zn}$ at 30 uM could neither reduce the intracellular $\mathrm{Cd}$ content nor promote induction of Cd-thionein. This indicates that the protective effect of $\mathrm{Zn}$ is notdue to a decrease in the effective concentration of $\mathrm{Cd}$ in proliferating $\mathrm{T}$ cells, but rather due to competition between $\mathrm{Zn}$ and $\mathrm{Cd}$ in the $\mathrm{Zn}$-dependent processes of $\mathrm{T}$ cell proliferation. To further elucidate the $\mathrm{Zn}$-dependent processes in the proliferative response of $T$ cells, we determined the effective time point of the inhibitory action of $\mathrm{Cd}$ or the protecting action of $\mathrm{Zn}$ against $\mathrm{Cd}$. $\mathrm{Cd}$ was added to spleen cell cultures at various time-points after Con $\mathrm{A}$ addition, and ${ }_{\mathrm{H}-}$ thymidine uptake during the final $4 \mathrm{hr}$ of $48 \mathrm{hr}$ culture was determined. Cd effectively inhibited the thymidine uptake when added at $16 \mathrm{~h}$ after Con $\mathrm{A}$ stimulation, and thereafter the effect gradually decreased. The protecting effect of $Z n$ against $C d$ action was also effective within first $16 \mathrm{~h}$ after the mitogen stimulation. Con A-induced thymidine uptake by spleen cells began $24 \mathrm{~h}$ after the mitogen stimulation, and then most of proliferating $T$ cells stay 
before the $S$ phase of cell cycle at $16 \mathrm{~h}$ of the mitogen stimulation. These findings indicate that the $\mathrm{Zn}$-dependent sites expressed before the $\mathrm{S}$ phase of cell cycle are susceptible to $C d$ and critical for $T$ cell proliferation.

Thus the $\mathrm{Zn}$-dependent processes required for $\mathrm{T}$ cell proliferation, which are expressed before the $S$ phase of cell cycle, can be target(s) of the differential toxicity to $T$ cells. Zn enzymes such as DNA polymerase and thymidine kinase are well discussed in relation to $\mathrm{Zn}$ requirement in cell proliferation. The Cd-induced inhibition of uridine uptake in $\mathrm{T}$ cells however begins between 10 and $16 \mathrm{~h}$ after Con A stimulation. Then it is most $1 \mathrm{ikely}$ that the $\mathrm{Zn}$-dependent processes responsible for susceptiblity of $T$ cell proliferation occur not on $Z n$ enzymes involved in DNA synthesis but on some molecules activated or induced in the Gl phase follwed by induction of DNA synthesis.

\section{I. DETECTION OF ZINC-BINDING PROTEINS IN CONCANAVALIN A-STIMULATED T LYMPHO- CYTES}

Many different proteins appear or disappear during $T$ cell proliferation [14]. Some of them may be induced specifically during mitogen stimulation of $T$ cells, and require their association with $\mathrm{Zn}$ for processing proliferative response. We have therefore detected $\mathrm{Zn}$-binding proteins in mouse spleen cells stimulated with Con A. $65 \mathrm{Zn}$-blotting analysis of the cytosol fraction from Con A-stimulated spleen cells for $24 \mathrm{~h}$ showed induction of three $\mathrm{Zn}-$ binding proteins with approximate molecular weight of 49, 90 and 100KD typically recognized among many proteins op SDS-polyacrylamide gel. When cultured spleen cells were labeled with $65 \mathrm{Zn}$ in medium, $\mathrm{Zn}$-binding proteins of 49 and 100KD also were detected in Con A stimulated cells. Electrophoretic features of these two proteins with high affinity to $\mathrm{Zn}$ are different from those of some authentic $\mathrm{Zn}$ enzymes, and seemingly from those of protein kinase $C$ of about $80 \mathrm{KD}$. It is unkown whether they are the equivalents of lymphoid specific tyrosine kinase $p 56^{1 \mathrm{ck}}$ enhanced by $\mathrm{Zn} \mathrm{[15]} \mathrm{and} 11.5 \mathrm{KD} \mathrm{Zn}-\mathrm{binding}$ protein, parathymosine [16], respectively. It is conceivable that these $\mathrm{Zn}-$ binding proteins play a role as a target of $\mathrm{Zn}$ action in $\mathrm{T}$ cell proliferation.

In conclusion, our findings elucidate that $Z n$ plays a critical role in regulation of $T$ cell proliferation at the processes expressed before the $S$ phase, and suggest that the $\mathrm{Zn}$-dependent processes can be associated with specific Zn-binding proteins induced during proliferative response of $T$ cells. Further study is required to explain biological significance of these $\mathrm{Zn}$ binding proteins in regulation of $T$ cell proliferation.

\section{SUMMARY}

The in vitro proliferation of $T$ lymphocytes are highly susceptible to $\mathrm{Zn}$ depriviation and $\mathrm{Cd}$ addition. In order to define $\mathrm{Zn}$ status in $\mathrm{T}$ cell proliferation, toxicological and biochemical situation of $\mathrm{Zn}$ in proliferative response of $T$ cells was investigated by use of mouse spleen cell cultures stimulated by $\mathrm{T}$ cell-mitogen, Con $\mathrm{A}$. The inhibitory effect of $\mathrm{Cd}$ on $\mathrm{T}$ cell proliferation was protected specifically by $\mathrm{Zn}$. The protection by $\mathrm{Zn}$ was effective when $\mathrm{Zn}$ was added within $16 \mathrm{~h}$ after Con A stimulation. $\mathrm{Zn}$ addition affected neither $\mathrm{Cd}$ content in cells nor induction of $\mathrm{Cd}$-thionein. These findings indicate that $\mathrm{Zn-dependent} \mathrm{processes} \mathrm{expressed} \mathrm{before} \mathrm{the} \mathrm{S}$ phase of cell cycle are critical for $T$ cell proliferation and are targets susceptible to Cd. Moreover, electrophoretical analysis showed two unknown Zn-binding proteins ( 49 and 100KD) induced in spleen cells incubated with Con $A$ and radioactive $\mathrm{Zn}$. These $\mathrm{Zn-binding} \mathrm{proteins} \mathrm{may} \mathrm{be} \mathrm{associated} \mathrm{with} \mathrm{the} \mathrm{Zn-dependent} \mathrm{pro-}$ cesses critical for $T$ cell proliferation. 
REFERENCES

[1] Fraker, P. J., Gershwin, E. M., Good, R. A., and Prasad, A. S. (1986): Interrelationship between zinc and immune function. Fed. Proc., 45, 1474-1479.

[2] Good, R. A. (1989): A note on zinc and immunocompetence, in Zinc in Human Biology, ed. by Mills, C. F., Springer-Verlag, London, pp. 221-223.

[3] Fernandes, G., Nair, M., Onoe, K., Tanaka, T., Floyd, R., and Good, R. A. (1979): Impairment of cell-mediated immunity function by dietary zinc deficiency in mice. Proc. Nat1. Acad. Sci. USA, $\| 6,457-461$.

[4] Ohsawa, M. (1991): Nutritional and toxicological implication of trace elements in the immune response, in Nutritional and Toxicological Trace Elements in Human Health and Disease, ed. by Prasad, A. S., Wiley-Liss, Inc., New York, in press.

[5] Zanzonico, P.., Fernandes, G., and Good, R. A. (1981): The differential sensitivity of T-cell and B-cell mitogenesis to in vitro zinc deficiency. Cel1. Immunol., 60, 203-211.

[6] Williams, R. 0., and Loeb, L. A. (1973): Zinc requirement for DNA replication in stimulated human lymphocytes. J. Cel1 Biol., 58, 594-601.

[7] Pleau, J.-M., Gastinel, L. N., and Bach, J.-F. (1985): Thymulin. Methods Enzymol., 116, 269-279.

[8] Wu, F. Y.- $H_{0}$, and Wu, C.-W. (1987): Zinc in DNA replication and transcription. Ann. Rev. Nutr., N, 251-272.

[9] Csermely, P., Szamel, M., Resch, K., and Somogy, J. (1988): Zinc can increase the activity of protein kinase $C$ and contributes to its binding to plasma membranes in $T$ lymphocytes. J. Biol. Chem., 263, 6487-6490.

[10] Zalewski, Forbes, I. J., Giannakis, C., and Cowled, P. A., and Betts, W. H. (1990): Synergy between zinc and phorbol ester in translocation of protein kinase C to cytoske1ton. FEBS Lett., 273, 131-134.

[11] Ohsawa, M., Masuko-Sato, K., Takahashi, K., and Otsuka, F. (1986): Strain differences in cadmium-mediated suppression of lymphocyte proliferation in mice. Toxicol. Appl. Pharmacol., 84, 379-388.

[12] Otsuka, F., and Ohsawa, M. (1987): Differential effect of cadmium on T and $B$ cell proliferation induced by mitogens: Possible mediation by zinc, in Toxicology of Metals, ed. by Brown, S. S., and Kodama, Y., E11 is Horwood Ltd., Chichester, pp. 125-126.

[13] Otsuka, F., and Ohsawa, M. (1991): Differential susceptibility of T- and B-lymphocyte proliferation to cadmium: Relevance to zinc requirement in T-lymphocyte proliferation. Chem.-Biol. Interactions, 78, 193-205.

[14] Kettman, J., and Lefkovits, I. (1984): An attempt to assess the overa 11 diversity of murine T-cell using two-dimensional gel electrophoresis. Eur. J. Immunol., 14, 769-777.

[15] Pernelle, J.-J., Creuzet, C., Loeb, J., and Gacon, G. (1991): Phosphorylation of the lymphijd cell kinase p56 ck is stimulated by micromolar concentration of $\mathrm{Zn}^{2+}$. FEBS Letters, 281, 278-282.

[16] Brand, I. A ${ }^{3}$ Heinicke1, A., and S8ling, H.-D. (1991): Localization of a $11.5 \mathrm{kDa} \mathrm{Zn} \mathrm{Zn}^{+}$-binding protein (parathymosin) in different rat tissues. Cell type-specific distribution between cytosolic and nuclear compartment. Eur. J. Cel1 Biol., 54, 157-165. 